\title{
Determinants of Interest Rate Spread: Some Empirical Evidence from Kenya's Banking Sector
}

\author{
Moses C. Kiptui ${ }^{1}$ \\ ${ }^{1}$ Kenya School of Monetary Studies, Nairobi, Kenya \\ Correspondence: Moses C. Kiptui, Kenya School of Monetary Studies, P.O. Box 65041-00618, Ruaraka, Nairobi, \\ Kenya. Tel: 254-720-393-828; 254-20-864-6217. E-mail: Kiptuimc@ ksms.or.ke or moses.kiptui @ yahoo.com
}

Received: August 29, 2014

Accepted: September 28, $2014 \quad$ Online Published: October 25, 2014

doi:10.5539/ibr.v7n11p94

URL: http://dx.doi.org/10.5539/ibr.v7n11p94

\begin{abstract}
This paper analyzes the role played by bank and industry-specific factors as well as macroeconomic variables in the determination of interest margins in Kenya's banking sector. Decomposition of the spread using income and balance sheet of the banking sector as a whole and panel data analysis of 39 commercial banks yielded consistent results which highlight the significant role played by bank and industry specific factors and macroeconomic variables in interest rate spread determination. It is shown that between $7-10$ per cent of the interest margin was attributable to operating costs. Moreover, a 1 per cent increase in operating costs translates to 0.38 per cent increase in interest margins for the sample of banks studied. In addition, a 1 per cent increase in non-performing loans leads to an upward adjustment of interest margins by 0.12 per cent. Macroeconomic factors also contribute to changes in the interest margin. A 1 per cent increase in Treasury bill rates leads to an upward adjustment of interest margins by 0.1 per cent. Likewise, a 1 per cent increase in GDP growth and exchange rate variability results in 0.05 and 0.06 per cent increase in interest spread respectively. In contrast, a 1 per cent increase in loans-liabilities ratio (reflecting degree of intermediation) results in interest margin reduction by 0.17 per cent. The results therefore emphasize the need to improve banking sector efficiency, deal with non-performing loans and maintain general macroeconomic stability.
\end{abstract}

Keywords: interest rate spread, interest margin, commercial banks, decomposition of spread, panel data analysis

\section{Introduction}

The unusually high cost of financial intermediation in Kenya, as measured by the interest rate spread, is a major source of policy concern and has been haunting policy makers and analysts alike, for a while. This has generated a raging debate within the media; the general public and the banking sector regulator on why interest rate spreads (IRS) are high in Kenya, its effects on the economy and the kind of policies that can be implemented in order to reduce it.

High interest rate spread has far reaching effects on the growth of an economy as it works against the development of financial intermediation by discouraging savers. Rising interest spread discourages savings and investments, on the one hand, and raises concerns about the effectiveness of the bank-lending channels of monetary policy, on the other (Khawaja \& Din, 2007). Output and employment are also affected adversely by high interest rate spread. This is because large spread diminishes savings, which in turn narrows levels of borrowing and, thus, narrows investment in the economy. Consequently, the interest rate spreads (IRS) in an economy is an indicator of inefficiency and has important implications for the growth and development of such economy (Folawewo and Tenant, 2008). A more efficient banking system benefits the real economy by allowing higher returns for savers and lower borrowing costs for investors. Hence, a higher spread limits financing for potential borrowers (Ndung'u \& Ngugi, 2000).

High spread also hurts small and medium enterprises and encourages informality as the cost of acquiring capital increases. It also impacts on the standard of living as the portion of the population who wish to join the business world are discouraged since acquiring capital through credit would be expensive. Increased default rates come as a result of high interest spread as borrowers are not able to service their loans. High spreads lead to higher cost of capital, reduced investment and bias towards short term high risk investments. The resulting scenario is that productivity declines and therefore, business expansion stagnates meaning employment levels also stagnate. 
Studies on interest rate spread differ in scope and emphasis. Some studies use aggregate industry data while others apply disaggregated financial sector data. In most cases, bank and industry specific variables and macroeconomic variables are analyzed for their relative importance. A number of studies find that bank characteristics and industry specific variables play a major role. Jayaraman and Sharma (2003) found that high spreads in Pacific Island Countries is attributed generally to the presence of high intermediation costs, reflecting the weaknesses and inadequacies of the financial sectors. After-tax profit margin contributes in a major way to the size of the interest spread. Administrative cost and loan loss provisioning expense are also found to be important causes of the interest rate spread. Ramful (2001) in a study of the Mauritian banking sector shows that interest rate spread is used to cover the costs of operating expenses and required reserves. Spread also reflects the prevalence of market power and compensates for the quality of loans. Asset quality measured by the provision of bad and doubtful debts is found to be positively related to spread. It is found that banks with high non-interest income can, in general, afford to narrow their spread.

Barajas, Teiner, and Salazar (1999) studied the Colombian banking sector and found that operational costs, financial taxation and loan quality determine spread. In their study of Pakistan, Khawaja and Din (2002) show that inelasticity of deposit supply is a major determinant of interest spread whereas industry concentration has no significant influence on interest spread. Similarly, a study by Brock and Suarez (2000) shows that high operating costs raise spreads as do high levels of non-performing loans, although the size of these effects differs across the countries. In addition, reserve requirements in a number of countries still act as a tax on banks that gets translated into a higher spread. Saunders and Schumacher (2000) decompose bank margins into a regulatory component, a market structure component and a risk premium component. The regulatory components in the form of interest-rate restrictions on deposits, reserve requirements and capital-to-asset ratios have a significant impact on banks interest margin. The study also attributes high spread to monopoly power of existing banks. Hesse (2007) analyzed the individual bank spreads from 2000-2005 in Nigeria. They observed that larger banks enjoyed lower overhead costs than smaller banks and also charged lower spreads. The study shows that both liquidity and equity holdings are negatively related to spreads.

The role of macroeconomic variables has been emphasized in several studies. A study by Afanasieff, Lhacer and Nakane (2002) suggest that macroeconomic variables are the most relevant factors explaining the behavior of bank interest rate spreads in Brazil. Crowley (2007) found that higher spreads are associated with lower inflation. Similarly, a study by Brock and Suarez (2000) shows that beyond bank specific variables, uncertainty in the macroeconomic environment facing banks appears to increase interest spreads. Saunders and Schumacher (2000) argue that interest-rate volatility has a significant impact on bank interest margins. In their study of Uganda, Hesse and Beck (2007) confirm the importance of macroeconomic factors, such as high inflation, high T-Bill rates and exchange rates. Hesse (2007) finds that low inflation and Treasury bill rates as well as a stable exchange rate can be conducive to lower spreads and therefore cause a more efficient channeling of savings to productive investments. The study by Folawewo and Tennant, (2008) shows that the extent of government crowding out in the banking sector, public sector deficits, discount rate, inflationary level and the level of money supply are important determinants of interest rate spreads in Sub-Saharan African countries.

There are few studies on Kenya's banking sector. Ndung'u and Ngugi (2000) examine the relationship between spread, depoits, t-bill rate, and interbank rate using monthly data covering the period 1993(4)-1999(6). The factors that drive the interest rate spread are found to include availability of deposits, the proportion of non-performing loans and fiscal policy actions which increase Treasury bill rates and exacerbate inflationary pressure thus calling for tight monetary policy. A closely related study by Ngugi (2001) using monthly data from 1991(7) to 1999(12) attributes widening of interest rate spreads to use of reserve requirements which imposes implicit costs, lack of reforms of the legal system, banks maintaining profit margins, tightening of monetary policy and increase in treasury bill rates as well as macroeconomic instability. Both papers however do not use disaggregated banking sector data. The approach adopted in the current study therefore differs since we make use of individual commercial banks data in addition to macroeconomic variables to analyze factors driving interest rate spread in Kenya's banking sector using panel data on 39 Kenyan banks. A recent study on the Kenyan banking sector by Were and Wambua (2013) however apply panel data analysis on disaggregated banking sector data to study interest rate spread. They found that bank-specific factors play a significant role in the determination of interest rate spreads. Industry specific factors and macroeconomic factors are insignificant. The study however uses a simple measure of spread i.e. difference between lending rate and deposit rate. This measure is adversely affected by the composition of lending of individual banks. The current study uses a more appropriate measure of interest rate spread which is more comparable across banks.

The purpose of this study therefore is to deepen understanding on the factors contributing to interest rate spreads 
in Kenya's banking sector so as to resolve debates on the possible causes of the relatively high spread. These debates can only be resolved through objective, quantitative analysis of the determinants of banking sector interest rate spreads. Such analysis would facilitate policy interventions to reduce spread.

The rest of the paper is organized as follows: section 2 examines trends in interest rate spreads in African countries; section 3 presents the methodology applied; section 4, the empirical results; section 5 concludes the study.

\section{Trends in Interest Rate Spreads in African Countries}

Interest rate spreads for selected African countries as shown below in figure 1 indicates that spread is driven by various factors. Whereas spread has been declining in Kenya, Namibia and Tanzania, it has been rising in Rwanda, Mauritius and Botswana. Spread has been rising and falling in Uganda with little net effect over the period. In Kenya spread has been on a downward trend following liberalization though still remaining relatively high. Uganda has relatively persistent high interest spread among the selected countries while South Africa experiences relatively lower interest rate spread. Beck and Hesse (2009) attribute the high and persistent Ugandan spread to among other factors high cost of doing business, high T-bill rates, institutional deficiencies and high inflation. South Africa's spread is much lower and declining at a steady rate compared to that of Kenya. Although Botswana's spread is on a rising trend, it has been lower than that of Kenya.

Spreads vary widely across countries. Moreover, the relative size of cross-country margins appears to change over time. Following liberalization, policymakers expected that interest rate spreads would converge to international levels. It was expected that with increased competition, market forces would reduce and keep bank spreads at levels similar to those prevailing in industrialized economies. Narrow spread would have signalled the success of financial sector reforms and liberalization. The persistence of high spreads even after liberalization thus calls for a better understanding of the behaviour of interest rate spreads. Knowledge generated relating to spread will therefore benefit not only the regulator but also Government in the formulation of appropriate interventions.

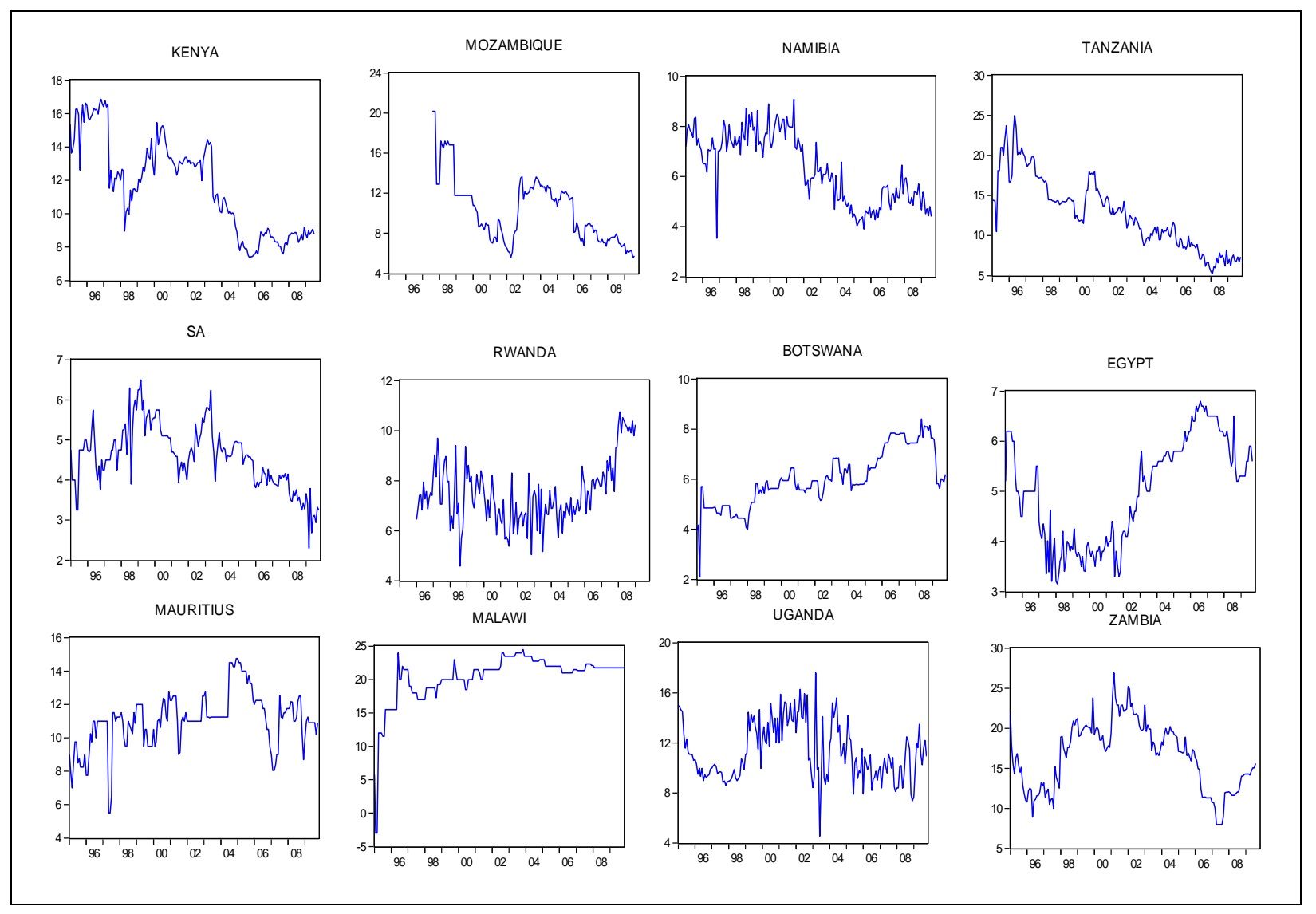

Figure 1. Interest rate spreads for selected African countries 


\section{Methodology}

This study applies two methods in anlaysis; decomposition technique and panel data analysis. The decomposition approach combines data from income statements and consolidated balance sheets of commercial banks to analyze the spread.

\subsection{Decomposition of the Spread}

Following Randall (1998) income statements and balance sheets of commercial banks can be used to derive an accounting framework to decompose the interest rate spread.

The consolidated income statement of commercial banks is used to derive the following:

$$
\pi=(T I I+N I I)-(T I E+T O E)-L L P
$$

Where

$\pi$ is profit before taxes (operating profit);

TII is total interest income;

NII is non interest income;

TIE is total interest expenses;

TOE is total operating expenses;

LLP is total loan loss provisions.

Equation (1) states that profit is total income minus (-) total expenses minus (-) total loan loss provisions.

Rearranging this relationship of consolidated income statement of commercial banks, we can derive the interest margin i.e. the difference between interest income and interest expense.

$$
T I I-T I E=\pi+T O E+L L P-N I I
$$

Dividing through by Deposits and using Loans and Assets:

$$
T I I * \frac{L}{L * D}-\frac{T I E}{D}=\frac{\pi}{A} * \frac{A}{D}+\frac{T O E}{D}+\frac{L L P}{D}-\frac{N I I}{D}
$$

Where

$\frac{\pi}{A}$ is gross return on assets (ROA).

In line with Randall (1998), the ratio of loans to deposits (L/D) is one minus required reserve ratio yielding:

$$
\frac{T I I}{L} *(1-r r)-\frac{T I E}{D}=R O A * \frac{A}{D}+\frac{T O E}{D}+\frac{L L P}{D}-\frac{N I I}{D}
$$

Thus:

$$
\frac{T I I}{L}-\frac{T I E}{D}=r r * \frac{T I I}{L}+R O A * \frac{A}{D}+\frac{T O E}{D}+\frac{L L P}{D}-\frac{N I I}{D}
$$

Where $\left(\frac{T I I}{L}-\frac{T I E}{D}\right)$ is implicit average interest rate spread and;

$\frac{T H}{L}$ is implicit average lending rate;

$\frac{T I E}{D}$ is implicit average deposit rate;

$\mathrm{rr}$ is required reserve ratio, where $\mathrm{L} / \mathrm{D}=1-\mathrm{rr}$;

ROA is return on assets.

The decomposition of the spread is done using equation (5) which states that interest rate spread equals required 
reserves multiplied by total interest income divided by loans plus(+) return on assets multiplied by assets divided by deposits plus(+) total operating expenses divided by deposits plus(+) total loan loss provisions divided by deposits minus(-) non-interest income divided by deposits. These computations will be implemented on an annual basis in a tabular format over the period of the study. From this analysis it should be possible to see the percentage contribution of each of the factors included.

\subsection{Panel Data Estimation}

In order to incorporate industry and macroeconomic factors in addition to bank-specific factors, panel data analysis will be carried out with banks' interest rate margins as dependent variable using a fixed effects approach. Thus, we estimate the following fixed effects model:

$$
\text { int erest } m \text { argin } i_{i, t}=\alpha_{i}+x_{i, t}^{\prime} \beta+\varepsilon_{i, t}
$$

Where $\mathrm{x}_{\mathrm{i}, \mathrm{t}}$ is a $\mathrm{k}$-dimensional vector of explanatory variables. It is assumed that a change in $\mathrm{x}$ will lead to the same effects on interest margin for all banks over the period but the average level for each bank will differ. The $\alpha_{\mathrm{i}}$ captures effects of factors peculiar to the $\mathrm{i}^{\text {th }}$ bank and that are constant overtime. In the fixed effects model, $\alpha_{\mathrm{i}}$ represents fixed parameters. The model does not impose any restrictions on the relationship between $\alpha_{\mathrm{i}}$ and $\mathrm{x}_{\mathrm{i}, t}$. This is unlike the random effects model which suffers inconsistent estimators in the event that $\alpha_{\mathrm{i}}$ and $\mathrm{x}_{\mathrm{i}, \mathrm{t}}$ are correlated.

\subsection{Description of Data}

The data consists of annual observations obtained from commercial banks financial statements. Comparative data was also obtained from the International Financial Statistics of IMF. Data covers the period from 1999-2008 and across 39 banks. The vector of explanatory variables covers bank and industry-specific data and macroeconomic data as enumerated below.

\subsubsection{Bank and Industry -Specific Data}

(1) Provision for doubtful debts as a ratio of total loans or non-performing loans to total loans - inverse indicator of the quality of assets and intended to capture credit risk. Positive relationship expected with spread.

(2) Ratio of operating cost (including wage bill) to total assets. Positive relationship with spread expected.

(3) Ratio of each bank's deposits to total system deposits - Market share of each commercial bank in the deposit market as an indicator of size to test the efficient market hypothesis or existence of economies of scale. To the extent that market shares get translated into market power, banks with higher shares of the market may be able to charge higher rates on loans. On the other hand, large banks may be able to reap economies of scale and may pass on some of these benefits to their customers in the form of lower spreads. Therefore market share view predicts a negative relationship with spread while the market power view predicts a positive relationship.

(4) Liquidity is measured as ratio of liquid assets to total assets (sometimes defined as liquid assets relative to short-term liabilities). Liquid assets refer to cash and deposit balances in other banks (including reserve requirements at the CBK). This is a cost to banks and is self-imposed for prudential reasons or as a result of regulation (reserve requirement). Positive relationship is expected.

(5) Ratio of bank equity to total assets- positive relationship expected since holding large equity ratios either on a voluntary basis or as a result of regulation can be costly for banks. Holdings of excessive capital increase opportunity costs. New capital requirements could therefore affect spreads.

(6) Herfindahl index in the deposit and lending market segment - defined as the sum of squared market shares in the deposit or loan market segment scaled by 1000 (ranges from 0 to 1)- measures banking sector concentration or extent to which loans/ deposits are concentrated on the hands of few banks within the system. A positive sign on the coefficient is an indication of greater market power and less competition in the sector.

(7) Intermediation defined as total loans over total liabilities- banks involved in intermediation of loans better prepared for competition and charge lower spread.

\subsubsection{Macroeconomic Data}

Bank spreads can be affected by macroeconomic environment in which banks operate so there is need to control for the inflation rate, the real output growth, Treasury bill rate and exchange rate variability.

(1) Change in consumer price index or inflation - if inflation shocks are not passed through both rates equally fast then spreads should reflect this.

(2) Change in output or GDP growth- as output growth slows down during the business cycle, credit 
worthiness deteriorates and other things equal this is likely to be reflected in the higher bank loan rates.

(3) Treasury bill rate- proxies for the marginal cost of funds- could also proxy for alternative investment opportunities of banks.

(4) Exchange rate stability (proxied by exchange rate standard deviation over the last twelve months).

Table 1. Definition of variables used

\begin{tabular}{ll}
\hline Variable & Definitions \\
\hline Time-variant bank-level variables & \\
Interest margin (S1) & $\begin{array}{l}\text { interest on loans \& advances over loans \&advances to customers minus (-) } \\
\text { interest on deposits over total deposits }\end{array}$ \\
Capital ratio & Ratio of bank equity to total assets \\
Liquidity ratio & Ratio of liquid Assets to Total assets \\
Non-performing loan ratio & Ratio of Total non-performing loans to Total loans \\
Cost ratio & Ratio of total operating expense to Total assets. Total operating expenses include \\
Market share (deposits) & $\begin{array}{l}\text { general administrative expenses and other operating costs. } \\
\text { Degree of intermediation }\end{array}$ \\
Time-variant sector and macro variables & Total loans over total liabilities \\
Exchange rate stability/ variability & \\
Inflation rate & Standard deviation of exchange rate over the last 12 months \\
Treasury bill rate & Per cent change in CPI \\
GDP growth rate & 91-day treasury bill rate \\
Herfindahl index-loans & Real GDP growth rate \\
\hline
\end{tabular}

\section{Empirical Results}

\subsection{Descriptive Statistics}

\subsubsection{Interest Margin Measure}

The interest margin measure used in estimation is defined as interest on loans and advances over loans and advances to customers minus interest on deposits over total deposits. Looking at the trend of the interest rate margin, it is clear that this has been on a downward trend ultimately stabilizing in the period after 2004 (figure 2).

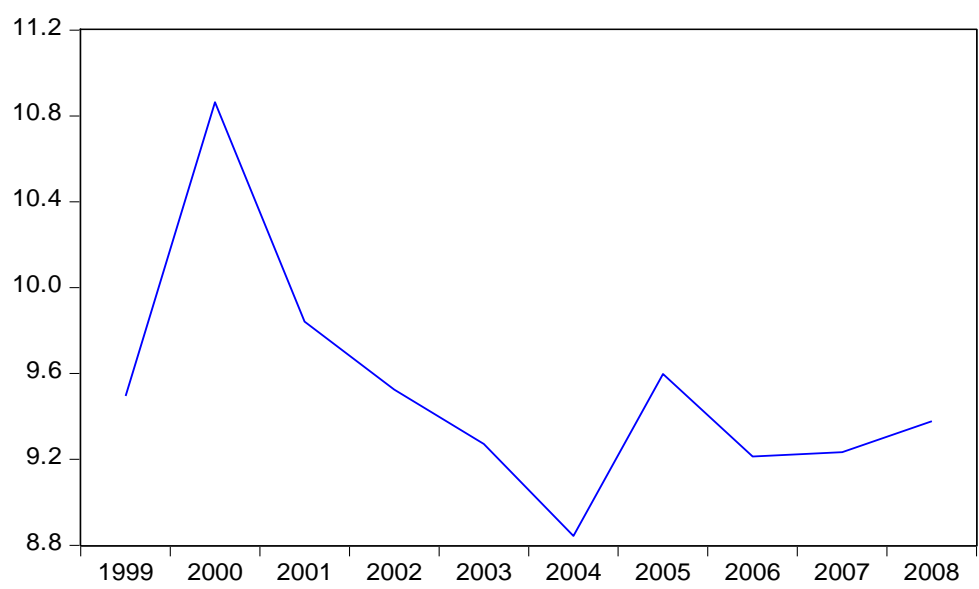

Figure 2. Interest margin (banking sector average) 


\subsubsection{Lending, Deposit Rates and Interest Margin}

Average lending rate is highly correlated with average deposit rate (see figure 3). However, when compared with spread, deposit rates appear to be weakly related to spread while the lending rate appears highly correlated with spread implying that adjustments in the lending rates could contribute more to changes in spread. Therefore spread could be reduced if sustained reduction in lending rates is achieved.
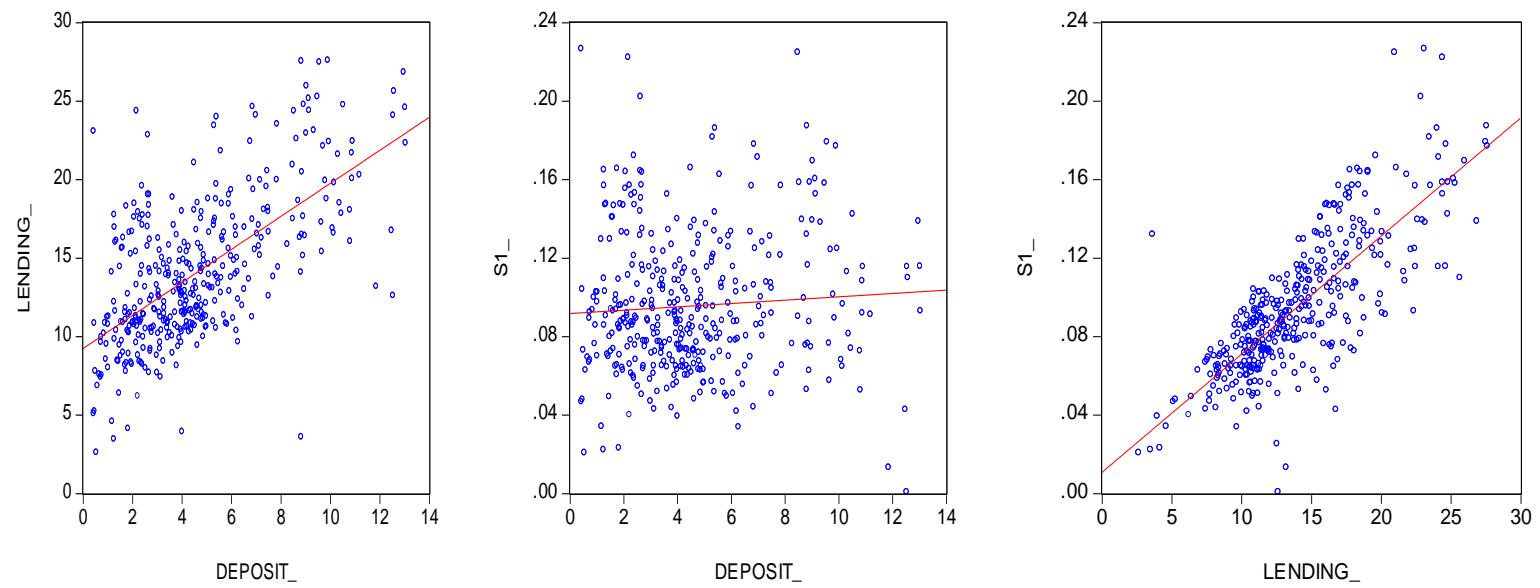

Figure 3. Comparing average lending and deposit rates and interest margin (s1)

\subsubsection{How Are Lending Rates Relating with Key Spread (Interest Margin) Determinants?}

Given the strong correlation between spread and lending rates, the factors influencing spread are also highly correlated with lending rates as shown in figure 4 below. It is clear that lending rates are positively correlated with capital ratios, non-performing loans and cost ratios.
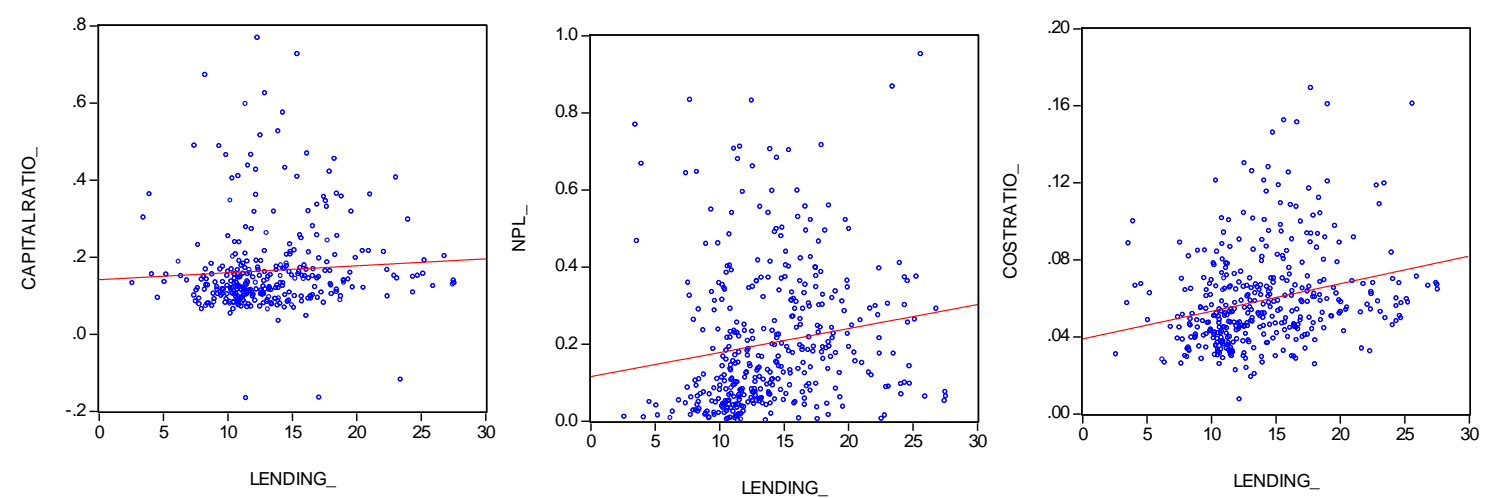

Figure 4. Lending rates and key spread determinants

\subsubsection{Interest Margins and Bank-Specific Factors: General Trends and Correlations}

To relate interest rate margins and bank-specific variables, averages for the whole financial sector are computed. The non-performing loans are positively correlated with interest margins at levels and in differences (see table 2a $\& 2 b)$. Non-performing loans has declined persistently since 2000 .

Cost ratio represented by the ratio of operating expenses to total assets is positively correlated with interest margin at levels and also in differences ( 0.50 in both cases). Cost ratio declined and has moved closely with spread over the entire period. 
The liquidity ratio declined in 1999-2002. Since 2003 it rose, peaking in 2007 before declining again. Liquidity is positively correlated with interest margin at levels and in differences.

Table 2a. Correlation table of bank-specific variables with interest margin-in levels

\begin{tabular}{|c|c|c|c|c|c|c|c|}
\hline & $\begin{array}{l}\text { interest } \\
\text { margin }\end{array}$ & capital ratio & $\begin{array}{l}\text { liquidity } \\
\text { ratio }\end{array}$ & Intermediation & $\begin{array}{c}\text { non-performing } \\
\text { loans }\end{array}$ & cost ratio & $\begin{array}{c}\text { interest income } \\
\text { share }\end{array}$ \\
\hline interest margin & 1.00 & & & & & & \\
\hline capital ratio & 0.13 & 1.00 & & & & & \\
\hline liquidity ratio & 0.04 & 0.10 & 1.00 & & & & \\
\hline intermediation & 0.14 & 0.54 & -0.13 & 1.00 & & & \\
\hline non-performing loans & 0.11 & 0.30 & -0.06 & 0.55 & 1.00 & & \\
\hline cost ratio & 0.50 & 0.30 & -0.04 & 0.43 & 0.38 & 1.00 & \\
\hline interest income share & -0.04 & -0.24 & 0.05 & -0.20 & -0.09 & -0.47 & 1.00 \\
\hline
\end{tabular}

Table 2b. Correlation table of bank-level variables with interest margin- in differences

\begin{tabular}{lccccccc}
\hline & $\begin{array}{c}\text { D(INTEREST } \\
\text { MARGIN) }\end{array}$ & $\begin{array}{c}\text { D(CAPITAL } \\
\text { RATIO) }\end{array}$ & $\begin{array}{c}\text { D(COST } \\
\text { RATIO) }\end{array}$ & $\begin{array}{c}\text { D(INTEREST } \\
\text { INCOME SHARE) }\end{array}$ & $\begin{array}{c}\text { DINTERME- } \\
\text { MEASURE) }\end{array}$ & $\begin{array}{c}\text { D(LIQUIDITY } \\
\text { RATIO) }\end{array}$ & D(NPL) \\
\hline D(INTEREST & 1.00 & & & & & \\
MARGIN) & 0.29 & 1.00 & & & & \\
D(CAPITAL RATIO) & 0.50 & 0.38 & 1.00 & & & \\
D(COST RATIO) & & & & & & & \\
D(INTEREST & 0.11 & -0.47 & 0.36 & 1.00 & & & \\
INCOME SHARE) & & & & & & \\
D(INTERMEDIATION & -0.15 & 0.09 & -0.02 & 0.50 & 1.00 & & \\
MEASURE) & 0.30 & -0.40 & 0.22 & 0.25 & -0.16 & 1.00 & \\
D(LIQUIDITY RATIO) & 0.90 & 0.23 & 0.37 & -0.16 & -0.36 & 0.45 & 1.00 \\
D(NPL) & &
\end{tabular}

\subsection{Decomposition of the Spread}

From table 3, it can be observed that the percentage points attributable to various costs (reserve costs, operational costs and loan loss provisions) varied over the 10-year period. Operating costs accounted for the largest percentage points. Operating costs accounted for 10 percentage points in 1999 and its attributable effects have declined gradually to 7.3 percentage points in 2008. The portion attributable to Reserve costs also declined from $2.4 \% 1999$ to $1.2 \% 2008$. The percentage points attributable to loan loss provisions declined from 5.6 in 1999 to 0.5 in 2008. Non-interest income on the other hand did not change much, declining from 6.0 in 1999 to 5.2 in 2008. The combined effect of reduced reserve costs, loan loss provisions and operating costs was an increase in return on assets from $1.0 \%$ in 1999 to $4.1 \% 2008$.

Overall, therefore, operating costs continue to play an important role in the determination of the interest rate spread. The role played by loan loss provisions has continued to diminish overtime.

The residual element is due to errors of combining flow data from income statements and stock data from consolidated balance sheet and also due to the assumption that Loans as a proportion of deposits (loanable funds) is deposits net of required reserves i.e. $\mathrm{L}=(1-\mathrm{rr}) * \mathrm{DD}$. 
Table 3. Decomposition of interest margin (in percent)

\begin{tabular}{|c|c|c|c|c|c|c|c|c|c|c|}
\hline & 1999 & 2000 & 2001 & 2002 & 2003 & 2004 & 2005 & 2006 & 2007 & 2008 \\
\hline interest income/loans & 20.0 & 18.1 & 16.7 & 16.5 & 15.9 & 14.4 & 15.8 & 15.6 & 17.0 & 19.5 \\
\hline interest expense/deposits & 7.1 & 6.4 & 5.0 & 3.7 & 2.3 & 1.4 & 2.7 & 2.7 & 2.7 & 3.2 \\
\hline Spread $^{\mathrm{z}}$ & 12.9 & 11.7 & 11.7 & 12.7 & 13.7 & 12.9 & 13.2 & 12.9 & 14.3 & 16.3 \\
\hline $\mathrm{rr}$ & 12.0 & 12.0 & 10.0 & 10.0 & 8.0 & 6.0 & 6.0 & 6.0 & 6.0 & 6.0 \\
\hline $\mathrm{rr}^{*}$ interest income/loans ${ }^{\mathrm{a}}$ & 2.4 & 2.2 & 1.7 & 1.6 & 1.3 & 0.9 & 0.9 & 0.9 & 1.0 & 1.2 \\
\hline (operating cost/deposits ${ }^{\mathrm{b}}$ & 10.0 & 9.1 & 8.7 & 8.6 & 7.9 & 7.6 & 7.8 & 7.6 & 7.8 & 7.3 \\
\hline provision for losses on loans and advances ${ }^{\mathrm{c}}$ & 5.6 & 4.0 & 2.5 & 2.8 & 2.0 & 1.7 & 1.3 & 1.3 & 0.8 & 0.5 \\
\hline Return on assets $*$ Assets/Deposits ${ }^{\mathrm{d}}$ & 1.9 & 1.2 & 2.7 & 2.1 & 3.9 & 3.2 & 3.8 & 4.4 & 4.7 & 5.1 \\
\hline Non-interest income $\mathrm{e}^{\mathrm{e}}$ & 6.0 & 5.6 & 5.8 & 5.8 & 6.1 & 5.5 & 5.3 & 5.6 & 5.5 & 5.2 \\
\hline Residual $^{\mathrm{f}}$ & -1.0 & 0.9 & 1.9 & 3.3 & 4.7 & 5.0 & 4.6 & 4.3 & 5.5 & 7.5 \\
\hline
\end{tabular}

spread, $z=a+b+c+d-e+f$.

\subsection{Panel Estimation Results}

In this section, I report results from panel regressions. Initial panel estimations yielded insignificant results for liquidity, market share (deposits), herfindahl index (loans) and inflation (see appendix table 2). These variables were subsequently dropped from the estimated model. As already noted by Čihak' and Podpiera (2005), concentration of the banking system in Kenya is low as shown by low herfindahl index. This could explain why market share and herfindahl index are insignificant determinants of spread.

The panel regressions in table 4 show that the capital ratio has significant positive effects on interest margin as expected implying that banks holding large equity ratios have to pass on the cost by charging higher interest margins. Another expected result is the significant positive effect of non-performing loans on interest margins. The decline in non-performing loans signalled reduced credit risk hence pushing down interest rate margins. Further decline in non-performing loans is therefore desirable.

The cost ratio is highly significant and positive as expected. Cost reduction over the period has therefore contributed to reduced interest margin. Further decline in costs and improved efficient operations of commercial banks is important in bringing down and maintaining low interest margins.

The degree of intermediation as proxied by the loan-liabilities ratio is highly significant and negative as expected suggesting that banks which are more involved in intermediation of loans charge lower interest margins.

The Macroeconomic environment also has significant effects on interest margins. Improved economic performance or growth exerts an upward pressure on interest margins most likely arising from the increased demand for credit. Economic growth is however significant at the 10 per cent level of significance. Increased exchange rate instability (proxied by rising standard deviations of nominal exchange rate from the mean) exerts highly significant positive effects on interest margins. Similarly, Treasury bill rate has significant positive effects on interest margins.

Table 4. Panel estimation of interest margin equation

\begin{tabular}{ccccc}
\hline \multicolumn{2}{l}{ Dependent Variable: Interest Rate Margin } & & & \\
\hline Variable & Coefficient & Std. Error & t-Statistic & Prob. \\
\hline Constant & 3.352744 & 1.107560 & 3.027144 & 0.0027 \\
Capital ratio & 0.063171 & 0.024996 & 2.527216 & 0.0121 \\
Intermediation measure & -0.020591 & 0.006949 & -2.963433 & 0.0033 \\
Cost ratio & 0.629320 & 0.125607 & 5.010214 & 0.0000 \\
Non-performing loans & 0.057708 & 0.016732 & 3.448924 & 0.0007 \\
GDP growth & 0.128298 & 0.067434 & 1.902563 & 0.0581 \\
Exchange rate variability & 0.258003 & 0.088280 & 2.922543 & 0.0038 \\
Treasury bill rate & 0.118633 & 0.044562 & 2.662184 & 0.0082 \\
Fixed Effects & - & - & - & - \\
\hline
\end{tabular}




\begin{tabular}{lc}
\hline R-squared & 0.66 \\
Adjusted R-squared & 0.61 \\
F-statistic & 11.95 \\
Prob(F-statistic) & 0.00 \\
\hline Computed Elasticities & \\
\hline Capital ratio & 0.11 \\
Intermediation measure & 0.17 \\
Cost ratio & 0.38 \\
Non-performing loans & 0.12 \\
GDP growth & 0.05 \\
Exchange rate variability & 0.06 \\
Treasury bill rate & 0.10 \\
\hline
\end{tabular}

From the computed elasticities, the panel estimation results suggest that an increase of the capital (equity-assets) ratio by 1 per cent would result in an upward adjustment of 0.11 percent in interest margins. Similarly, an increase in the non-performing loans as a ratio of total loans by 1 percent results in an increase in interest margins by 0.12 percent while a rise in loans-liabilities ratio (as a measure of the degree of intermediation) by 1 per cent leads to a downward adjustment of interest margins by 0.17 percent.

Overall, the greatest increase in interest margins results from an increase in operating expenses (in this case as a ratio of assets). When operating expenses as a ratio of assets rises by 1 percent, interest margins are adjusted upwards by 0.38 percent. The Treasury bill rate also exerts a positive effect on interest margins. As Treasury bill rates rise by 1 percent, interest margins are adjusted upwards by 0.10 percent.

The Macroeconomic environment also has significant effects on interest margins. Improved economic performance or growth exerts an upward pressure on interest margins most likely arising from the increased demand for credit. An increase in economic growth by 1 percent leads to an increase in interest margins by 0.05 percent. Exchange rate instability on the other hand exerts positive effects on interest margins. An increase of exchange rate instability/ variability (measured in standard deviations from mean) by 1 percent results in an upward adjustment of interest margins by 0.06 percent.

The results obtained in this study are to a large extent consistent with findings of previous studies. The finding that operating costs and non-performing loans contribute significantly to interest rate spread is supported by Were and Wambua (2013) despite the fact that they used a different measure of spread. Though Were and Wambua (2013) did not include Treasury bill rate in their study, the significance of this variable in the current study is in line with findings of Ndung'u and Ngugi (2000) and Ngugi (2001). Inflation is found insignificant in this study and is also insignificant in Were and Wambua (2013). It is important however to note that Were and Wambua (2013) chose somehow different variables compared to what is used in this study. They did not include capital ratio, intermediation measure and exchange rate variability which have been found significant determinants in this study.

Like other methodologies, panel data analysis is subject to certain limitations. In the estimation, observations are pooled across banks which force the coefficients in the spread equation to be similar for all banks. Regarding the comparison of results obtained using the decomposition technique and panel data analysis; it should be pointed out that the decomposition technique cannot incorporate industry-wide variables as well as macroeconomic variables. The decomposition technique is therefore useful in so far as it illustrates the key bank-specific factors driving interest rate spread. However, despite these challenges, this study is able to offer great insights on the determinants of interest rate spread in Kenya.

\section{Conclusion and Policy Implications}

In this study, interest margins are hypothesized to be a function of bank and industry specific variables, the macroeconomic environment and market structure. Fixed effects panel estimation is applied on data obtained from commercial banks financial statements and published in the Banking survey. The data covers 39 commercial banks.

Decomposition of the spread using income statements and balance sheets of commercial banks shows that 
between 7.3 percent and 10 percent of the interest margin over the period of study was attributable to operating costs. Operating costs therefore accounted for a significant portion of the spread or interest margin. Reserve ratio accounted for 1.2 percent to 2.4 percent of the interest margin while loan loss provisions accounted for 0.5 percent to 5.6 percent.

The panel estimations yielded consistent results with operating costs turning out to be highly significant and with highest interest margin elasticity implying that bank specific factors indeed play a significant role in determining interest rate margins. In addition to operating costs, the capital ratio has significant positive effects on interest margin as expected implying that banks holding large equity ratios pass on the cost by charging higher interest margins. Non-performing loans also have significant positive effects on interest margins.

Macroeconomic factors contribute to the interest margin. The Treasury bill rate reflecting the interplay between fiscal and monetary policies has significant positive effects on interest margins. Likewise, GDP growth has significant positive effects. It is noteworthy that exchange rate instability has significant positive effects on interest rate spread.

The results suggest that a 1 percent increase in operating costs translates to 0.38 percent increase in interest margin. Likewise, the elasticity of interest margins with respect to non-performing loans is 0.12 implying that a 1 per cent increase in non-performing loans would lead to an upward adjustment of interest margins by 0.12 percent. Similarly, a 1 percent increase in Treasury bill rates leads to an upward adjustment of interest margins by 0.1 percent while a 1 percent increase in GDP growth and exchange rate variability would result in increases in interest margins by 0.05 and 0.06 percent respectively. In contrast, a 1 percent increase in loans-liabilities ratio (intermediation measure) results in reduction in interest margins by 0.17 .

The study clearly shows that tackling the interest spread problem requires coordinated efforts and a combination of fiscal and monetary policy actions. Policy actions pursued need to conform to the objective of further improving efficiency in the banking sector which in turn will reduce operational costs and hence impact favourably on interest rate spreads. The policies pursued with regard to non-performing loans in Kenya have so far borne fruit. Privatization of public owned banks has contributed to reduced non-performing loans over the study period and has thus had favourable effects on interest margins.

Maintaining macroeconomic stability is essential in the pursuit of low interest margins as demonstrated by the significant role played by Treasury bill rates and exchange rate stability in the determination of interest margins in Kenya's banking sector.

\section{References}

Afanasieff, T. S., Lhacer, P. M., \& Nakane, M. (2002). Determinants of bank Interest rate spread in Brazil. Research Department, Bank of Brazil. Retrieved from http://www.bcb.gov.br/pec/wps/ingl/wps46.pdf

Arize, C., Malindretos, J., \& Ike Obi, Z. (2002). Long- and short-term interest rates in 19 countries: tests of cointegration and parameter instability. Atlantic Economic Journal, 30, $105-120$. http://dx.doi.org/10.1007/BF02299156

Barajas, A., Teiner, R., \& Salazar, N. (1999). Interest rate spread in banking in Colombia. IMF Staff Papers, 46, 196-224. Retrieved from http://www.imf.org/external/pubs/ft/wp/wp98110.pdf

Berg, S. A., \& Kim, M. (1998). Banks as multi-output oligopolies: An empirical evaluation of the retail and corporate banking markets. Journal of Money, Credit and Banking, 30, $135-153$. http://dx.doi.org/10.2307/2601206

Berger, A. N., \& Mester, L. J. (1997). Inside the black box: What explains differences in the efficiencies of financial institutions? Journal of Banking \& Finance, 21, 895-947. http://dx.doi.org/10.1016/S0378-4266(97)00010-1

Brock, P. L., \& Suarez, L. R. (2000). Understanding the behaviour of bank spread in Latin America. Journal of Development Economics, 63, 113-134. http://dx.doi.org/10.1016/S0304-3878(00)00102-4

Cihak, M., \& Podpiera, R. (2005). Bank behaviour in developing countries: Evidence from East Africa. IMF Working Paper WP/05/129. Retrieved from https://www.imf.org/external/pubs/ft/wp/2005/wp05129.pdf

Crowley, J. (2007). Interest rate spread in English-speaking African countries. IMF Working Paper 101. http://dx.doi.org/10.5089/9781451866650.001

Favero, C. A., Giavazzi, F., \& Spaventa, L. (1997). High yields: The spread on the German interest rate. The Economic Journal, 107, 956-985. http://dx.doi.org/10.1111/j.1468-0297.1997.tb00002.x 
Folawewo, A. O., \& Tennant, D. (2008). Determinants of Interest Rate Spread in Sub Saharan African countries: A Dynamic Panel Analysis. Paper prepared for $13^{\text {th }}$ annual African econometric society conference (pp. 9-11). Retrieved from http://www.africametrics.org/documents/conference08/day2/session6/folawewo_tennant.pdf

Hesse, H. (2007). Financial intermediation in the pre-consolidated banking sector in Nigeria. World Bank Policy Research Working Paper. Retrieved from http://www-wds.worldbank.org/servlet/WDSContentServer/WDSP/IB/2007/06/21/000016406_2007062110 3202/Rendered/PDF/wps4267.pdf

Hesse, H., \& Beck, T. (2007). Why are interest rate spread so high in Uganda? Journal of Development Economics, 88, 192-204. Retrieved from http://www.sciencedirect.com/science/article/B6VBV-4T35NK5-1/2/05a8c6dc4b5aad96667ef1d9c88caa15

Jayaraman, T., \& Sharma, R. (2003). Why is Interest rate spread high in Fiji? Results from a preliminary study. Fijian Studies: A Journal of Contemporary Fiji, 1(1), 75-104. Retrieved from http://search.informit.com.au/documentSummary;dn=746642772435691;res=IELIND

John C., Cox, J. C., Ingersoll, J. E. Jr., \& Ross, S. A. (1985). A theory of the term structure of interest rates. Econometrica, 53, 385-407. http://dx.doi.org/10.2307/1911242

Khawaja, I., \& Din, M. (2007). The determinants of interest rate spread in Pakistan. Pakistan Institute of Development Economics, PIDE Working Papers 2007 (p. 22). Retrieved from http://www.pide.org.pk/pdf/Working\%20Paper/Working\%20Paper-22.pdf

Lang, L. H., Litzenberger, R., \& Liu, A. (1998). Determinants of interest rate swap spread. Journal of Banking and Finance, 22, 1507-1532. http://dx.doi.org/10.1016/S0378-4266(98)00068-5

Ndungu, N. S., \& Ngugi, R. W. (2000). Banking sector interest rate spread in Kenya. KIPPRA Discussion Paper, No. 5. Retrieved from http://eldis.org/go/home\&id=4397\&type=Organisation\&more=yes\#.VABIRPmSw8w

Ngugi, R. (2001). Empirical Analysis of interest rate spread in Kenya. African Economic Research Consortium $\begin{array}{lrr}\text { paper } & \text { No.106. } & \text { Retrieved } \\ \text { http://dspace.africaportal.org/jspui/bitstream/123456789/32054/1/rp106.pdf? }\end{array}$

Park, K. H., \& Weber, W. L. (2006). Profitability of Korean banks: Test of market structure versus efficient

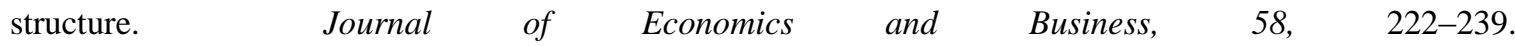
http://dx.doi.org/10.1016/j.jeconbus.2005.09.003

Ramful, P. (2001). Determinants of interest rate spread: Empirical evidence in Mauritian banking sector. Research Department, Bank of Mauritius. Retrieved from https://www.bom.mu/pdf/Research_and_Publications/Research_Papers/spread.htm

Saunders, A., \& Schumacher, L. (2000). The Determinants of interest rate margin: An international study. Journal of International Money and Finance, 19, 813-832. http://dx.doi.org/10.1016/S0261-5606(00)00033-4

Sharpe, S. A. (1990). Asymmetric information, bank lending and implicit contracts: A stylized model of customer relationships. The Journal of Finance, 45, 1069-1087. Retrieved from http://www.jstor.org/stable/pdfplus/2328715.pdf?acceptTC=true\&jpdConfirm=true

Were, M., \& Wambua, J. (2013). Assessing the determinants of interest rate spread of commercial banks in Kenya: an empirical investigation. Kenya Bankers Association, WPS/01/13. Retrieved from http://www.kba.co.ke/workingpaperseries/img/pdf/Working_Paper_WPS_04_12[2].pdf 


\section{Appendix}

Appendix 1. Descriptive statistics

\begin{tabular}{lccccccccc}
\hline \multirow{2}{*}{ Variable } & & & \multicolumn{7}{c}{ Coefficient of } \\
& Mean & Median & Maximum & Minimum & Std. dev. & variation & Skewness & Kurtosis & Observations \\
\hline Interest margin & 9.53 & 8.90 & 22.67 & 0.09 & 3.56 & 37.39 & 0.75 & 3.84 & 390 \\
Capital ratio & 16.54 & 13.23 & 76.80 & -16.66 & 11.89 & 71.86 & 2.06 & 9.00 & 320 \\
GDP growth & 3.58 & 3.36 & 7.10 & 0.55 & 2.23 & 62.12 & 0.08 & 1.64 & 390 \\
Herfindahl index(loans) & 0.10 & 0.10 & 0.11 & 0.09 & 0.01 & 8.82 & -0.20 & 1.67 & 390 \\
inflation & 8.98 & 8.17 & 17.82 & 1.62 & 5.11 & 56.96 & 0.47 & 2.11 & 390 \\
liquidity & 17.97 & 16.06 & 66.21 & 2.24 & 8.98 & 49.99 & 1.29 & 5.74 & 386 \\
Intermediation measure & 76.16 & 73.09 & 265.08 & 20.11 & 33.90 & 44.51 & 1.75 & 8.72 & 387 \\
Market share (deposits) & 2.58 & 0.91 & 20.19 & 0.01 & 4.16 & 161.03 & 2.57 & 9.04 & 387 \\
Non-performing loans ratio & 20.31 & 14.98 & 95.15 & 0.11 & 18.07 & 88.96 & 1.34 & 4.69 & 387 \\
Cost ratio & 5.91 & 5.30 & 16.91 & 0.74 & 2.54 & 43.01 & 1.43 & 5.64 & 386 \\
Exchange rate variability & 2.29 & 1.82 & 5.88 & 0.50 & 1.79 & 77.89 & 1.09 & 2.78 & 390 \\
Treasury bill rate & 8.35 & 8.07 & 13.29 & 2.96 & 3.37 & 40.37 & -0.02 & 1.92 & 390 \\
\hline
\end{tabular}

Appendix 2. Initial panel Regression including insignificant variables

\begin{tabular}{lcccc}
\hline Dependent Variable: Interest Margin & & & \\
\hline Variable & Coefficient & Std. Error & t-Statistic & Prob. \\
C & 2.554456 & 3.115443 & 0.819934 & 0.4130 \\
Capita ratio & 0.071201 & 0.026481 & 2.688724 & 0.0076 \\
liquidity & 0.014976 & 0.022033 & 0.679724 & 0.4973 \\
Intermediation measure & -0.020114 & 0.007722 & -2.604758 & 0.0097 \\
Market share (deposits) & 0.210691 & 0.185005 & 1.138838 & 0.2558 \\
Cost ratio & 0.656615 & 0.129193 & 5.082440 & 0.0000 \\
Nonperforming loans & 0.060117 & 0.018381 & 3.270548 & 0.0012 \\
GDP growth & 0.123544 & 0.077724 & 1.589528 & 0.1131 \\
Exchange rate variability & 0.283237 & 0.157639 & 1.796740 & 0.0735 \\
Herfindahl index (loans) & -2.363239 & 25.18121 & -0.093849 & 0.9253 \\
inflation & -0.009781 & 0.049849 & -0.196215 & 0.8446 \\
Treasury bill rate (91day) & 0.107325 & 0.066162 & 1.622149 & 0.1059 \\
Fixed Effects (Cross) & - & - & - & - \\
\hline R-squared & 0.66 & & & \\
Adjusted R-squared & 0.60 & & & \\
F-statistic & 10.93 & & & \\
Prob(F-statistic) & 0.00 & & & \\
Durbin-Watson stat & 1.56 & & & \\
\hline & & & & \\
\hline
\end{tabular}



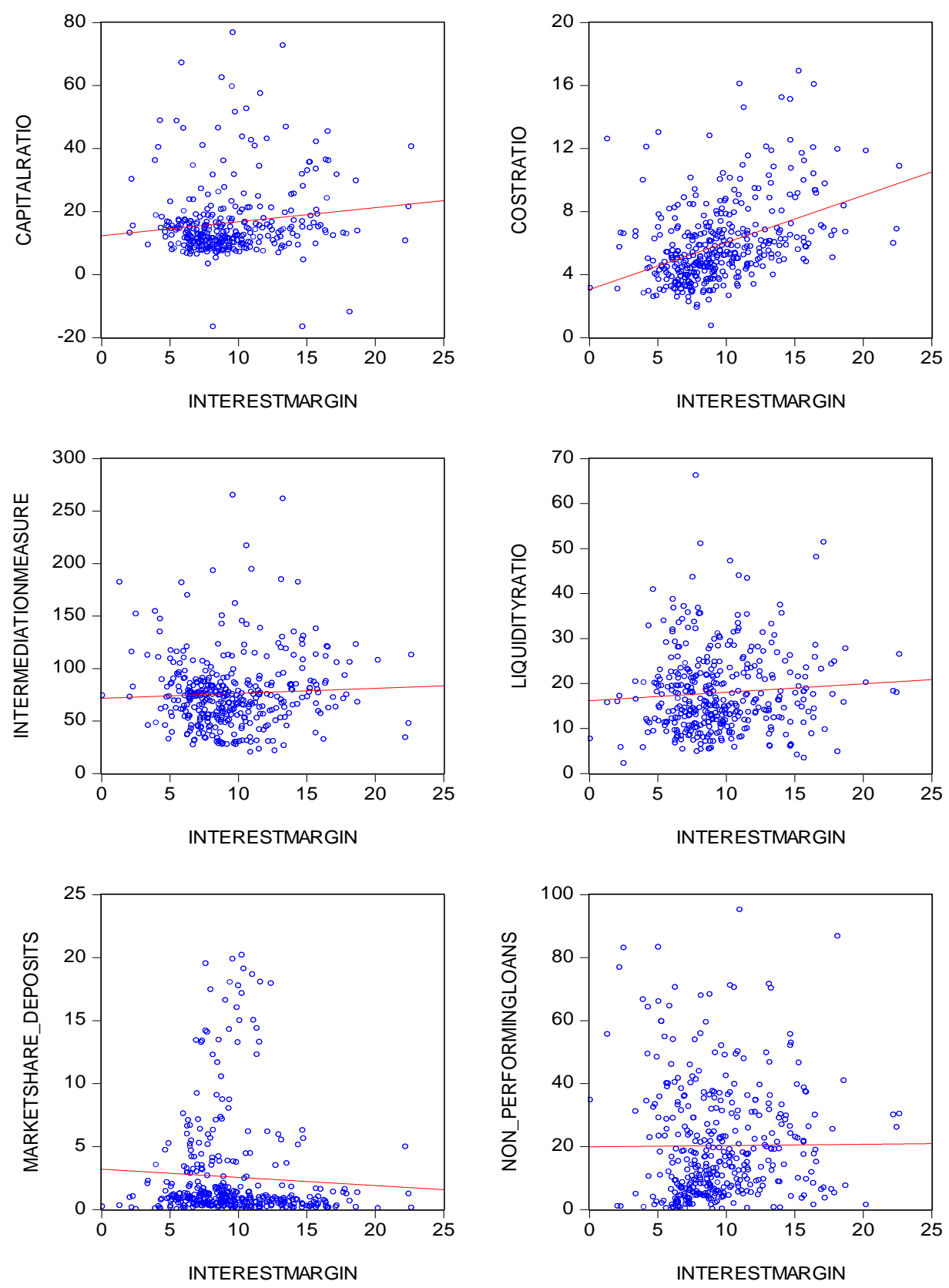

Appendix 3. Relating interest margins and its determinants

\section{Copyrights}

Copyright for this article is retained by the author(s), with first publication rights granted to the journal.

This is an open-access article distributed under the terms and conditions of the Creative Commons Attribution license (http://creativecommons.org/licenses/by/3.0/). 